\title{
The Choice of Content on Social Networks by Adolescents, Depending on Their Life Purposefulness
}

\author{
Tatyana Gavrilova ${ }^{1, *}$, Oksana Markova ${ }^{1}$, Tatyana Popova ${ }^{2}$, Tatyana Slinkova ${ }^{1}$, Faina \\ Shvets ${ }^{1}$, Natalya Skomorokhova ${ }^{1}$ \\ ${ }^{1}$ Department of Educational Psychology, Far Eastern State University, Ussuriysk, Russia \\ ${ }^{2}$ Psychological Institute of the Russian Academy of Education, Moscow Institute of Psychoanalysis, Moscow, Russia \\ *Corresponding author.Email: tgavrilovaster@gmail.com
}

\begin{abstract} adolescents. VKontakte

\section{INTRODUCTION}

At present, the question of the formation of lifelong orientations of adolescents cannot be considered outside the context of the virtual environment of the younger generations. Such studies are actively conducted both in our country and abroad [1-4].

The purpose of the study is to identify the effect of life commitment on the choice of content content on social networks by adolescents. If there is influence, then how do interests differ among adolescents with low and high determination. The study is a fragment of a broader project devoted to the study of the psychological characteristics of adolescents interested in prosuicidal content on social networks.
\end{abstract}

The results of a study of the interests of adolescents on the VKontakte social network and the degree to which their goals are expressed in life are presented using the "Goal in Life" scale of D.A. Leontyev's questionnaire of meaningful life orientations and the author's profile of interests. The study showed that life sense of purpose is higher for those adolescents who choose topics of making money and gaining popularity on social networks and lower for those who are looking for content on topics of life and death on social networks. The choice of themes of love of friendship and humor was not related to the life determination of

Keywords: adolescent psychology, interests, lifelong orientations, Internet services, social networks,

\section{METHODOLOGY}

The research design of the project included two samples: online sampling and offline sampling. An online sample was formed by contacting the group administrators who allowed us to post our test. In total, 200 respondents aged 13-18 years old (average age 15.2 years, 125 females and 75 males) completed our online survey questionnaire.

An offline sample was drawn by schoolchildren 13-18 years old, studying in schools of the Primorsky Territory and the Moscow Region (average age 15.2 years, $\mathrm{N}=308$, 169 women and 139 men; Moscow Region $\mathrm{N}=195$,
Primorsky Territory $\mathrm{N}=113$ ). In total, the study covered 508 adolescents (294 females and 214 males), average age 15.2 years).

To assess the meaningfulness of the future, we used the "Goals in Life" scale (5 points) from D. Leontiev's Test of Meaning-Life Orientations [5]. Answers were given on a 5-point scale: "Very much like me", "Mostly like me", "Somewhat like me", "Not much like me", "Not like me at all". One question was asked to assess thematic interests: "What kind of content on social networks would interest you (choose no more than three topics)" and five topics were suggested: a) how to make money; b) about love and friendship; c) about life and death; d) humor; e) how to become popular. Respondents were also asked to indicate their gender and age.

The questionnaire was placed on two web pages of a personal account using the Google Forms online service: one for online selection (link: https://docs.google.com/forms/d/1DPnOHug92sSsAA0oj _qaoNHSxAV4aZi3bP5naUbHkIk/edit) and one for offline selection (link: https://docs.google.com/forms/d/1y4bQHSDmU6aA6z6Ct sYyKF-h5aO4Ht84RCZ0RoObpac/edit). Students from the offline sample passed the test on mobile phones in the presence of the teacher at school, participation in the test was voluntary. 


\section{RESULTS}

First, we compiled a hierarchy of interests of adolescents in social networks by the percentage of those who chose each topic to the total number of adolescents in the sample
(Table 1), then, using the Mann-Whitney criterion, we estimated the differences in the average indicators on the "Goal in Life" scale between those who chose a specific topic and those who did not choose it (Tab. 2-7).

Table 1. Hierarchy of interests of teenagers in social networks

\begin{tabular}{|c|c|c|c|}
\hline $\begin{array}{c}\text { Topics of interests of adolescents in } \\
\text { social networks }\end{array}$ & Rank & $\%$ & $\begin{array}{c}\text { Frequency (number } \\
\text { of selections) }\end{array}$ \\
\hline Humor & 1 & 70,3 & 357 \\
\hline About love and friendship & 2 & 42,3 & 215 \\
\hline About life and death & 3 & 41,3 & 210 \\
\hline How to make money & 4 & 28,7 & 146 \\
\hline How to become popular & 5 & 15,9 & 81 \\
\hline
\end{tabular}

The relations between interests and indicators of meaningfulness of life were analyzed by assessing the differences in the average scores of the indicators of the

"Goal in Life" scale (point-by-point and on the whole

Table 2. Average scores on the "purpose for life" scale, depending on the choice "how to make money" as an interesting content in social networks

\begin{tabular}{|c|c|c|c|}
\hline $\begin{array}{c}\text { Scale "Goals in life" of the Test of life- } \\
\text { meaning orientations (the points) }\end{array}$ & $\begin{array}{c}\text { Choose "How to } \\
\text { make money" }\end{array}$ & $\begin{array}{c}\text { Did not choose } \\
\text { "How to make } \\
\text { money" }\end{array}$ & $\begin{array}{c}\text { significance of } \\
\text { these differences by the } \\
\text { Mann-Whitney test }\end{array}$ \\
\hline $\begin{array}{c}\text { I do not have specific goals and } \\
\text { and aimless }\end{array}$ & $2,24,03 *$ \\
\hline $\begin{array}{c}\text { My life seems extremely meaningless } \\
\text { would say that it was quite meaningful }\end{array}$ & 2,15 & 2,57 & $\mathbf{0 , 0 0 1 * *}$ \\
\hline $\begin{array}{c}\text { I have not yet found my calling and clear } \\
\text { goals in life }\end{array}$ & 3,49 & 3.28 & 0,07 \\
\hline My life views have not yet been decided & 3,04 & 3,21 & 0,14 \\
\hline $\begin{array}{c}\text { I believe that I managed to find a calling } \\
\text { and interesting goals in life }\end{array}$ & 3,32 & 3,07 & 0,80 \\
\hline General commitment to life in general & 20,3 & 3,06 & $\mathbf{0 , 0 2 *}$ \\
\hline
\end{tabular}

Table 2 shows that there are significant differences on three points and on the scale as a whole: adolescents who choose the topic of money assess the existence of a goal in scale) between groups that chose one or another interest (Table 2-6).

Table 3. Average scores on the "purpose for life" scales, depending on the choice "on love and friendship" as an interesting content in social networks

\begin{tabular}{|c|c|c|c|}
\hline $\begin{array}{c}\text { Scale "Goals in life" of the } \\
\text { Test of life-meaning } \\
\text { orientations (the points) }\end{array}$ & $\begin{array}{c}\text { These "On love and } \\
\text { friendship" }\end{array}$ & $\begin{array}{c}\text { Did not choose "On love } \\
\text { of these } \\
\text { and friendship" }\end{array}$ & $\begin{array}{c}\text { differences by } \\
\text { the Mann- } \\
\text { Whitney test }\end{array}$ \\
\hline
\end{tabular}




\begin{tabular}{|c|c|c|c|}
\hline $\begin{array}{c}\text { I do not have specific goals } \\
\text { and intentions in life }\end{array}$ & 2,36 & 2,49 & 0,27 \\
\hline $\begin{array}{c}\text { My life seems extremely } \\
\text { meaningless and aimless }\end{array}$ & 2,35 & 2,53 & 0,15 \\
\hline $\begin{array}{c}\text { If I had to summarize my } \\
\text { life today, I would say that it } \\
\text { was quite meaningful }\end{array}$ & 3,44 & 3,27 & 0,12 \\
\hline $\begin{array}{c}\text { I have not yet found my } \\
\text { calling and clear goals in life }\end{array}$ & 3,08 & 3,22 & 0,25 \\
\hline $\begin{array}{c}\text { My life views have not yet } \\
\text { been decided }\end{array}$ & 3,05 & 3,08 & 0,79 \\
\hline $\begin{array}{c}\text { I believe that I managed to } \\
\text { find a calling and interesting } \\
\text { goals in life }\end{array}$ & 3,20 & 3,08 & 0,24 \\
\hline $\begin{array}{c}\text { General commitment to life } \\
\text { in general }\end{array}$ & 19,8 & & 19,0 \\
\hline
\end{tabular}

Table 3 shows that significant differences were not identified on any point and on the scale as a whole: adolescents who choose the topic of love and friendship

Table 4. Average scores on the "purpose in life" scale, depending on the selection "on life and death" as an interesting content in social networks

\begin{tabular}{|c|c|c|c|}
\hline $\begin{array}{c}\text { Scale "Goals in life" of the Test } \\
\text { of life-meaning orientations (the } \\
\text { points) }\end{array}$ & $\begin{array}{c}\text { Choose "On } \\
\text { Life and } \\
\text { Death" }\end{array}$ & $\begin{array}{c}\text { Did not choose } \\
\text { "On Life and } \\
\text { Death" }\end{array}$ & $\begin{array}{c}\text { The significance of these } \\
\text { differences by the Mann- } \\
\text { Whitney test }\end{array}$ \\
\hline $\begin{array}{c}\text { I do not have specific goals and } \\
\text { intentions in life }\end{array}$ & 2,81 & 2,17 & $\mathbf{0 , 0 0 0 * *}$ \\
\hline $\begin{array}{c}\text { My life seems extremely } \\
\text { meaningless and aimless }\end{array}$ & 2,95 & 2,10 & $\mathbf{0 , 0 0 0 *}$ \\
\hline $\begin{array}{c}\text { If I had to summarize my life } \\
\text { today, I would say that it was } \\
\text { quite meaningful }\end{array}$ & 3,14 & 3,48 & $\mathbf{0 , 0 0 1 * *}$ \\
\hline $\begin{array}{c}\text { I have not yet found my calling } \\
\text { and clear goals in life }\end{array}$ & 3,44 & 2,96 & $\mathbf{0 , 0 0 0 * * *}$ \\
\hline $\begin{array}{c}\text { My life views have not yet been } \\
\text { decided }\end{array}$ & 3,17 & 2,99 & 0,10 \\
\hline $\begin{array}{c}\text { I believe that I managed to find a } \\
\text { calling and interesting goals in } \\
\text { life }\end{array}$ & 17,6 & 3,30 & $\mathbf{0 , 0 0 0 * * *}$ \\
\hline
\end{tabular}

Table 4 shows that there are significant differences on five points and on the scale as a whole: adolescents who evaluate the existence of a goal in life in the same way as adolescents who did not choose this topic. 
Table 5. Average scores on the "purpose for life" scale, depending on the choice of "humor" as an interesting content in social networks

\begin{tabular}{|c|c|c|c|}
\hline $\begin{array}{c}\text { Scale "Goals in life" of the Test } \\
\text { of life-meaning orientations (the } \\
\text { points) }\end{array}$ & $\begin{array}{c}\text { Choose } \\
\text { "Humor" }\end{array}$ & $\begin{array}{c}\text { Did not choose } \\
\text { "Humor" }\end{array}$ & $\begin{array}{c}\text { The significance of these } \\
\text { differences by the Mann- } \\
\text { Whitney test }\end{array}$ \\
\hline $\begin{array}{c}\text { I do not have specific goals and } \\
\text { intentions in life }\end{array}$ & 2,44 & 2,43 & 0,94 \\
\hline $\begin{array}{c}\text { My life seems extremely } \\
\text { meaningless and aimless }\end{array}$ & 2,39 & 2,60 & 0,37 \\
\hline $\begin{array}{c}\text { If I had to summarize my life } \\
\text { today, I would say that it was } \\
\text { quite meaningful }\end{array}$ & 3,37 & 3,27 & \\
\hline $\begin{array}{c}\text { I have not yet found my calling } \\
\text { and clear goals in life }\end{array}$ & 3,16 & 3,15 & 0,93 \\
\hline $\begin{array}{c}\text { My life views have not yet been } \\
\text { decided }\end{array}$ & 3,07 & 3,05 & 0,84 \\
\hline $\begin{array}{c}\text { I believe that I managed to find a } \\
\text { calling and interesting goals in } \\
\text { life }\end{array}$ & 3,20 & 2,96 & \\
\hline $\begin{array}{c}\text { General commitment to life in } \\
\text { general }\end{array}$ & 19,5 & 19,00 & $\mathbf{0 , 0 3 *}$ \\
\hline
\end{tabular}

From table 6 it can be seen that no significant differences were found both on the scale as a whole and in almost all, with the exception of one point: teenagers who choose the theme of humor evaluate the existence of a goal in life in

Table 6. Average scores on the "purpose in life" scale, depending on the "how to become popular" choice as an interesting content in social networks

\begin{tabular}{|c|c|c|c|}
\hline $\begin{array}{c}\text { Scale "Goals in life" of the Test } \\
\text { of life-meaning orientations (the } \\
\text { points) }\end{array}$ & $\begin{array}{c}\text { Choose "How } \\
\text { to become } \\
\text { popular" }\end{array}$ & $\begin{array}{c}\text { Did not choose "How } \\
\text { to become popular" }\end{array}$ & $\begin{array}{c}\text { The significance of these } \\
\text { differences by the Mann- } \\
\text { Whitney test }\end{array}$ \\
\hline $\begin{array}{c}\text { I do not have specific goals and } \\
\text { intentions in life }\end{array}$ & 2,25 & 2,47 & 0,15 \\
\hline $\begin{array}{c}\text { My life seems extremely } \\
\text { meaningless and aimless }\end{array}$ & 2,25 & 2,49 & 0,13 \\
\hline $\begin{array}{c}\text { If I had to summarize my life } \\
\text { today, I would say that it was } \\
\text { quite meaningful }\end{array}$ & 3,65 & 3,28 & $\mathbf{0 , 0 1 *}$ \\
\hline $\begin{array}{c}\text { I have not yet found my calling } \\
\text { and clear goals in life }\end{array}$ & 2,95 & 3,20 & 0,11 \\
\hline $\begin{array}{c}\text { My life views have not yet been } \\
\text { decided }\end{array}$ & 2,94 & 3,09 & 0,32 \\
\hline $\begin{array}{c}\text { I believe that I managed to find a } \\
\text { calling and interesting goals in }\end{array}$ & 3,43 & & \\
\hline
\end{tabular}




\begin{tabular}{|c|c|c|c|}
\hline life & & & \\
\hline $\begin{array}{c}\text { General commitment to life in } \\
\text { general }\end{array}$ & 20,7 & 19,1 & $\mathbf{0 , 0 1 *}$ \\
\hline
\end{tabular}

From table 7 it is seen that there are significant differences on two points and on the scale as a whole: adolescents who choose the topic of popularity assess the existence of a goal in life higher than adolescents who do not choose this topic.

\section{CONCLUSION}

In general, the results of the study showed the following. Purposefulness in life is highest among adolescents who are interested in making money and gaining popularity in social networks ( $\mu=20.3$ and $\mu=20.7$, respectively). It is significantly higher than those who are not at all interested in these topics ( $\mu=18.9$ and $\mu=19.1$, respectively). Moreover, the topics of money and popularity occupy the last positions in the revealed hierarchy of interests $(15.7 \%$ and $28.7 \%$, respectively). In other words, life purposefulness is quite pragmatic in adolescents: make money and gain popularity. Indirectly, our data may also indicate that there are not very many purposeful teenagers among users of the VKontakte social network.

It also turned out that life purposefulness is the lowest among those who are searching on social networks for content on the topics of life and death $(\mu=17.6)$ as compared to those who have never chosen this topic $(\mu=$ 20.6) and those who chose other topics. This is expected, since this topic, within the proposed topic of choice, semantically reflects the search for the meaning of life.

Themes of love - friendship and humor, are apparently weakly connected with the life purposefulness of adolescents. These are, so to speak, universal interests. Although, if we compare the average indicators of purposefulness of adolescents who chose these topics, they will still be lower than those who chose the themes of money and popularity $(\mu=19.5$ and $\mu=19.7$ versus $\mu=$ 20.3 and $\mu=20,7$, respectively), but higher than that of adolescents who chose the theme of life and death $(\mu=$ 17.6). For all that, themes of love and humor turned out to be the most popular (70.3\% and $43.3 \%$, respectively).

Thus, we conclude that adolescents' motivation for life affects their choice of content topics on social networks. The data obtained can be of practical importance for the development of online programs to support the socialization of adolescents.

Study Limitations. Only one scale was used to assess life purposefulness and a limited range of topics for choosing interesting content on social networks, the vulnerable reliability of demographic and regional characteristics in data obtained through online surveys.

\section{REFERENCES}

[1] T.D. Martsinkovskaya, Information space as a factor in the socialization of modern adolescents, The World of Psychology 3 (2010) 90-102.

[2] K.N. Polivanova, I.B. Smirnov, What's in my profile for you: VKontakte data as a tool for studying the interests of modern adolescents, Education Issues 2 (2017) 134-152.

[3] V.S. Sobkin, A.V. Fedotova, A teenager in social networks: on the issue of socio-psychological wellbeing, National Psychological Journal 3(31) (2018) 2330 .

[4] L.A.S. Shapiro, G. Margolin, Growing up wired: social networking sites and adolescent psychosocial development, Clinical Child and Family Psychology Review 17(1) (2014) 1-18.

[5] D.A. Leontyev, Test of meaningful orientations, Sense, 1992. 